\title{
A MEMÓRIA EM TRẾS ATOS: DESLOCAMENTOS INTERDISCIPLINARES
}

Eliana de Freitas Dutra 



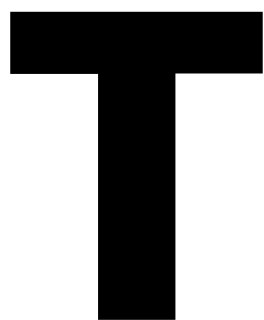

ema fascinante, a memória tem desafiado a ciência, a filosofia, a história, a literatura, as artes, e inspirado reflexões em diferentes registros epistemológicos, teóricos e estéticos. A sua presença nas tradições de pensamento da Antiguidade clássica, na história da sua organização nas famosas "artes de memória" inspiradas por tratados mnemônicos de origem greco-latina, a sua entrada no campo das teorias das ciências sociais, a noção contemporânea dos "lugares de memória" e os debates recentes no mundo público contemporâneo sobre seus usos, abusos e excessos, bem como sobre o "dever de memória", apenas aludem ao fato inequívoco de sua presença em diferentes e importantes momentos da história e da cultura ocidentais. Neste texto vamos nos ater à exploração da pertinência das relações entre história e memória no âmbito da epistemologia da história, e nas suas fronteiras com outras epistemologias.

Como somos seres de memória e de história, essas relações, por um lado, nos obrigam a pensar na dimensão humana da disciplina histórica e, por outro, nos remetem à reflexão sobre sua posição de relevo dentro de uma linha de preocupações importantes, qual seja, a dos lugares de renovação da his- toriografia contemporânea, a exemplo das novas hermenêuticas advindas das reflexões sobre os usos políticos do passado, as políticas de memória, a escrita da história.

A linha de abordagem a ser seguida neste texto origina-se do esforço de colocar em diálogo três abordagens da memória de naturezas distintas, as quais irão se desdobrando ao longo do texto: uma fílmica, que tem como suporte material um documentário; uma literária, onde a marca é a do recurso à ficção na forma de um romance; e uma hermenêutica, ancorada na questão da representação do passado e na constituição de uma forma de conhecimento, que é a memória, e de outra forma de conhecimento, que é a história.

Guardadas as especificidades dos seus respectivos lugares, nelas encontrei elementos para refletir sobre a problemática da memória e do esquecimento no campo do conhecimento histórico, e em cada uma recolhi substratos sobre a problemática da relação entre tempo e história, entre memória e esquecimento.

\section{MEMÓRIA EM CENA E CENAS DE MEMÓRIA}

Ao final do belíssimo documentário $L a$ Nostalgia de la Luz, produzido pela cineasta chileno Patrício Guzmán e por ele definido como "um filme sobre a memória" , o cineas-

\section{ELIANA DE} FREITAS DUTRA é professora titular do Departamento de História da UFMG e pesquisadora do CNPq.
1 Entrevista com Patrício Guzmán, in cinemadocumentaire. wordpress.com. 
ta se diz convencido de que "a memória tem uma força de gravidade, ela sempre nos atrai. Os que têm memória são capazes de viver no frágil tempo presente, os que não a têm não vivem em nenhuma parte" ${ }^{2}$. Essa frase tem a capacidade de sintetizar três linhas mestras que orientam o documentário em questão: a similaridade entre a força da memória e a força gravitacional, uma definindo a condição humana e a outra responsável pela mecânica do universo; o tempo, como elemento de ligação entre os homens e o universo, e matéria da memória; o tempo e a memória como condição da história humana.

Nesse documentário, um belo exercício poético sobre o cosmo, o tempo e a memória, seu realizador, no intuito de mostrar a importância do passado - do qual, ele insiste, tudo procede - e esconjurar seu esquecimento, escolheu um lugar, um território, o qual, segundo suas palavras, pertence ao passado: o deserto de Atacama.

Na sua aridez absoluta, o deserto nos é mostrado como um enorme palimpsesto de memória e de história. Nele se superpõem camadas geológicas e temporais, com suas sobrevivências pré-colombianas, tais como: animais petrificados, múmias, rochas com pinturas rupestres; restos de cadáveres dos trabalhadores nas minas de salitre e de soldados mortos no século XIX na disputa pelo controle das minas, a qual envolveu chilenos, peruanos e bolivianos; pedaços de corpos de presos políticos assassinados pela ditadura de Pinochet e para ali deportados e abandonados na expectativa de ficarem para sempre ocultados na sua imensidão.

Esse espaço, privilegiado para as observações e descobertas dos arqueólogos, apresenta condições excepcionais para a observação astronômica responsáveis pela instalação de um dos mais avançados observatórios do mundo, com modernos e potentes telescópios usados por equipes internacionais de astrônomos. E é pela via de um exercício metafórico sensível, e doloroso, que o cineasta vai estabelecer, no espaço do deserto de Atacama, uma aproximação entre as pesqui-

sas arqueológicas e astronômicas e a memó- ria da ditadura. E ele o faz justapondo um olhar para o alto, a observação das estrelas, cujo passado chega até o presente na forma de lembranças trazidas pela luz, e um olhar para o nível do solo, direcionado, um, pelas escavações em buscas de pistas e evidências da existência de outras culturas, outro, para a procura desesperada das mulheres pelos restos mortais dos seus familiares chilenos na terra calcinada do deserto.

Nesse esforço de aproximação não faltam, no documentário, depoimentos que, embora autorizados pelo exercício e a prática no interior dos domínios científicos da astronomia e da arqueologia, emprestam sua voz menos por razões científicas e mais pela empatia com a reflexão filosófica proposta pelo realizador do documentário, para quem "a memória é a coisa mais importante da vida. É o olhar do universo, o olhar da história, a mesma coisa que faz a teologia, a geologia, e as mulheres que buscam corpos". É nesse topos de buscas, e na realização do seu cruzamento, que a narrativa cinematográfica vai ser construída. Essa construção não vai prescindir das autodefinições dos personagens em meio às buscas que empreendem.

Assim é que ouvimos o astrônomo nos dizer que a pergunta mais importante que os astrônomos se fazem, "de onde viemos", se mescla com a cultura humana em geral", e que "o presente não existe a não ser como uma ilusão", pois não se vê nada no instante em que se vê, "tudo que vemos nos chega com atraso através da luz". O passado seria, portanto, o grande objeto dos astrônomos e, no seu entender, também dos arqueólogos e dos historiadores - ainda que estes estudem um passado mais próximo, restrito ao tempo da história dos homens, e os astrônomos, o mais longínquo, imerso no tempo do universo. Nesse jogo de identificações e definições em outro território comum, o da ciência, é o arqueólogo que define os astrônomos como "arqueólogos do espaço", que, no presente, recordam o passado, decifrando os enigmas do espaço, e o reconstroem através de pistas que a transparência do céu lhes permite encontrar, tal como o clima seco do deserto
Luz. Roteiro e direção de Patrício Guzmán. 
lhes permite, a eles, arqueólogos, controlar as evidências do passado. $\mathrm{O}$ ar transparente do deserto, segundo uma bela imagem de Guzmán, "permite ler neste grande livro de memória página, por página”. A chave para o êxito das buscas são as pistas, os traços de uma história preservados pela memória, numa aproximação com os historiadores cuja prática tem sido regida pelo chamado paradigma do traço ou do vestígio.

Aqui os depoimentos parecem confluir para a tentativa de presentificar o passado, dada a tensão temporal que faz com que o tempo presente só possa ser apreendido como passado, mantida a procura de fios que permitam compor formas para a memória; e para o esforço de presentificar o presente, já que a presença do presente é essencial ao imperativo ético da ação, a mensagem maior do documentário. Nessa linha de cruzamentos entre as práticas do astrônomo e do arqueólogo, e nas ligações buscadas entre os personagens que guiam nosso olhar sobre o deserto de Atacama, ouvimos o arqueólogo que não esconde sua perplexidade diante da possibilidade de se conhecer mil anos de história, enquanto vê ser esquecida no seu país a história de hoje - reafirmar a obrigação ética de se preservar a memória e não se esquecer dos mortos. A busca da origem da morte, expressa na persistência da busca dos restos mortais das vítimas da ditadura, a busca das origens do Universo, no estudo sistemático que varre as constelações e as galáxias, e a busca das origens das várias culturas dos povos pré-colombianos estão na base de uma mesma nostalgia da luz, grande metáfora da criação, da vida, da verdade, que o dever de memória impõe resgatar. Esse é o sentimento dos depoimentos de mães, viúvas, irmãs há anos vasculhando a terra seca do deserto tentando resgatar, com os fragmentos de vida encontrados, a totalidade dos que se foram. Recompor os corpos é a forma de recuperar a dignidade que sentem ter sido perdida. Astrônomos e arqueólogos, aqui, aparecem confrontados com a imposição "da experiência viva da memória, mas também com a especulação multimilenar sobre a ordem do tempo" (Ricoeur, 2000, p. 200), a exemplo dos historiadores.

Assim, à justaposição dos olhares para o céu e sobre a terra, são agregados outros elementos fundamentais: a construção, pelo regime de Pinochet, do campo de concentração de Chacabuco no local das ruínas das minas de salitre, e nas mesmas casas dos trabalhadores mineiros, as quais, segundo o depoimento de um ex-prisioneiro, só foi preciso cercar; a proibição pelos militares das atividades e estudos de um grupo de prisioneiros apaixonados pela astronomia - tal qual o realizador do filme na sua infância -, a pretexto de que planejavam fugir do campo de concentração se orientando pelas estrelas. Nesse ponto o cineasta entra em cena com um personagem que, como uma espécie de homem-memória, e com uma autoridade que nos recorda, guardada a devida distância, a dos mestres de verdade da Grécia arcaica (Dettienne, 1988) ${ }^{3}$, autentica a existência do campo de concentração retirando-o do esquecimento, e se lembrando do que ali foi apagado: os cabos eletrificados, as torres de vigilância, as cercas de arame.

Nesse ponto, tal como os memorialistas na sua palavra escrita, o homem-memória da prisão de Chacabuco mostra sua diferença da palavra mágico-religiosa do "mestre de verdade". Para este, a memória, mnemosine, era dom de vidência, de decifração do invisível, transcendência do tempo; para aquele, a memória é fato, é transfiguração do acontecimento, transparência do vivido, entrada e domínio do tempo, conquista do passado humano, certeza do presente. A esse homem o cineasta, como a reconhecer o direito de uma função social para a memória, dá a designação de "transmissor de história". E essa designação, considerada a condição de atestação do passado por parte da memória, como veremos à frente, pode ser corroborada por aqueles ${ }^{4}$ que creem num estatuto próprio da memória como conhecimento. A exigência de atestação da existência mesma de um passado teria sido transmitida à história, como modo de conhecimento, pela memória. Esse sujeito de memória, testemunha e fiador, ou
3 Dettienne nos fala da palavra cantada dos poetas, do seu estatuto mágico-religioso, da sua condição adivinhatória, que tem como suporte a memória como potência religiosa. Trata-se de uma memória divinizada que, se gundo Vernant (1990, pp. 105-48), não estava direcionada para a reconstrução do passado no interior de uma arquitetura temporal.

4 Nos referimos a $\mathrm{Ri}$ coeur (2000). Sobre esse ponto, no tocante às relações entre o ver o saber, conferir Hartog (2012, pp 203-28) e também Gagnebin (1992) 
5 Sobre as artes de memória bem como sobre os tratados clássicos dessa arte, exercida como parte da retórica, ver obelo livro de Yates (1974). transmissor da história, que aparece transitando pelo espaço feito de ruínas, inscreve a si mesmo como um traço de memória entre o tempo vivido no campo e o tempo construído pela memória.

Na sequência é a vez da entrada em cena de outro personagem nomeado como o "arquiteto de memória”. Esse ex-prisioneiro exercitou a sua memória, e parece ter criado suas próprias regras de mnemotecnia para a memorização das formas dos lugares, das medidas, das divisões dos cárceres, ou seja, dos lugares de detenção do campo de Chacabuco, nos fazendo lembrar as regras do clássico Instituto Oratório, de Quintiliano ${ }^{5}$, e seus métodos diretos de memorização pelo estudo cuidadoso, pela observação, pela repetição, ainda que, à diferença desses, seu exercício tenha se realizado numa direção sem qualquer relação com a arte da retórica - como de resto toda a arte de memória da Antiguidade clássica - e tivesse como companhia o silêncio, o quase segredo. Os desenhos eram feitos à noite, memorizados, escondidos e destruídos pela manhã. Dessa forma, quando no exílio e longe do campo, foi possível, pela recordação, refazê-los em detalhes e exibi-los como provas documentais do que viu e da infâmia que viveu. Herótodo, nas suas Historiès, registrou, como testemunha que viu e ouviu, as ações e os grandes e admiráveis feitos que não queria que fossem apagados com o tempo por julgá-los dignos de não se perderem para a memória dos homens. Já o "arquiteto de memória”, ao contrário, como testemunha e vítima de terríveis acontecimentos, registrou por escrito o cenário de ações indignas dos homens, na imperiosa necessidade de também reinscrevê-las na história.

A força do passado, como um dos suportes narrativos do documentário, é retomada pela presença, entre os astrônomos - hoje engajados no trabalho em torno da construção de um grande telescópio -, de um filho de mãe chilena, nascido no exílio, que enfatiza que a energia a ser captada pelas antenas do telescópio virá do passado chegando até o presente, mas que pertence à história do passado. Em seu depoimento, o jovem astrônomo se diz consciente de que ele e a mãe, que se ocupa de tratar os traumas sofridos por antigos prisioneiros políticos, "se movem no tempo do passado" e "trabalham com a informação do passado".

Outro elemento a reforçar as aproximações que guiam a narrativa do documentário na sua relação com o tempo, bem como com seu fio de busca de corpos celestes e humanos, é a sustentação, por um astrônomo americano da equipe do observatório de Atacama, de que a matéria do deserto, o cálcio, é também a das constelações de estrelas. "A matéria da terra era a mesma em todos os recôncavos do cosmo." E os ossos, nos diz Guzmán, são matérias perdidas no espaço, como os asteroides. E como traços do passado da história humana, ou do universo, urge que sejam recuperados para a memória.

As lentes de Guzmán, em La Nostalgia de la Luz, constrem o deserto de Atacama como uma paisagem memorial que ele devolve à história. Paisagem essa feita de traços escondidos, recalcados, de traumas e dramas silenciosos, mas também de traços que, através das condições climáticas do deserto, puderam persistir e sair das sombras e da escuridão em nome do resgate do humano. Persistência e lacuna: duas condições presentes no trabalho da memória e da história. A construção memorial acima aludida nos confirma que a memória também tem história, e que, no caso das histórias que tiveram como cenário o deserto de Atacama, o documentário de Guzmán foi definitivamente incorporado à sua tessitura. Sua narrativa, como a dos historiadores, é também expressão de uma relação entre passado e presente. Afinal, o que particulariza a história é o movimento, o trânsito constante entre passado e presente, e entre os diferentes momentos do passado. História e memória se valem de um tempo já transcorrido, e aquilo que projetam do presente para o futuro tem seu respaldo no passado, objeto, tal como memória de conflitos, disputas, interpretações. Vale lembrar que, na sua especificidade frente ao tempo natural, único, da astronomia, comum a to- 
dos os homens, o tempo da história - com sua arquitetura construída pelos historiadores na captura, no interior da vida social e política, dos seus múltiplos movimentos, das suas durações, dos seus vários ritmos, das suas rupturas e continuidades, das suas linhas entrecruzadas - comporta, para além de variados itinerários, diferentes formas de apreensão. As experiências temporais da história, vivenciadas pelos homens no seu presente, vão construir diferentes relações entre o passado e o futuro, as quais não prescindem da memória e das formas de lembrar.

No documentário de Guzmán, a força das imagens e os depoimentos que invocam a materialidade dos traços do passado como evidências em si mesmos não esbateram a realidade de sua construção e sua condição de representação, das quais o "cenário imaginário", como um dos recursos utilizados pelo cineasta para nos transportar as formas, cores e movimentos do cosmos, é apenas um detalhe. Por sua vez, a forte ênfase documentária no passado, aliada à carga afetiva que nos faz reviver os horrores da ditadura chilena, os quais se justificam como um fator consciente de ordem ética e política, não significa que o futuro não tenha lugar na relação entre tempo e memória. O futuro, ali, como para os historiadores, também procede do passado e das experiências nele vividas, quando aquele passado era o presente para os homens daquele tempo, com suas esperanças e expectativas por realizar.

Nesse belo documentário, que podemos denominar de objeto memorial, em que os procedimentos de criação do cinema ${ }^{7}$ foram colocados a serviço da memória, os historiadores são levados com delicadeza a refletir sobre questões que envolvem a memória e o tempo, e que os redirecionam ao seu domínio. Esse é caso das perguntas sobre as formas de sobrevivência do passado; as possíveis imperfeições da memória; suas descontinuidades e inevitável alteridade - esta, inscrita na diferença temporal entre o vivido e o momento da lembrança, sobre a qual já se disse, poeticamente, que "a impressão que temos é de enxergar o passado através de uma montanha de vidro" (Sebald, 2008, p. 158); as diferentes apreensões do tempo no mundo social; as relações da memória com a verdade, a criação, as formas de representação e as exigências de cientificidade; a presença da subjetividade. Essas indagações podem levar a exercícios de reflexão em outros territórios, nem tão próximos, nem tão distantes daquele do deserto de Atacama, mas igualmente capazes de, no contraste entre diferentes percepções e manuseios da memória, enriquecer as análises no campo da história e dotá-las de maior complexidade. Um desses territórios é o da ficção literária.

\section{ÀS VOLTAS COM A MEMÓRIA DE FLAUBERT}

No instigante livro O Papagaio de Flaubert - cuja intriga ficcional é um pretexto para o autor revisitar e problematizar a vida, a obra, as análises da obra e as correspondências de Flaubert, bem como os lugares onde o autor viveu -, o romancista inglês Julian Barnes (2000) mistura realidade e ficção numa fina e demolidora ironia literária contra os juízos dos biógrafos e críticos do escritor transformados em memória sobre ele ${ }^{8}$.

O personagem principal é o próprio Gustave Flaubert, e o narrador da história é um médico inglês, pretenso especialista na sua obra, alter ego do escritor Julian Barnes, o qual, nas pegadas do romancista francês, visita Rouen, cidade onde nasceu e morreu Flaubert. Lá descobre, num canto do museu do Hôtel-Dieu, onde o pai de Flaubert havia sido cirurgião, um papagaio empalhado, que teria sido emprestado ao escritor pelo Museu de Rouen para lhe servir de modelo enquanto escrevia seu célebre conto "Un Coeur Simple" (Flaubert, 1994). Em meio às várias peças e objetos ligados à história da medicina encontrava-se o papagaio, aliás, brasileiro, da região amazônica, o qual portava a devida etiqueta identificatória com a seguinte inscrição:

"Papagaio tomado emprestado por Gustave Flaubert ao Museu de Rouen, para ser co-
6 Entrevista com Patrício Guzmán, op. cit.

7 Tais como o som, as imagens, o uso da luz, os cortes, os enquadramentos, entre outros que aqui não foram trabalhados por excederem o objetivo deste texto.

8 Com inúmeras modificações nos valemos aqui, bem como na parte seguinte deste artigo, de ideias desenvolvidas no texto "O que É Avançado nas Ciências Humanas" (Dutra, 2006). 
9 Aqui, um pequeno parêntesis: as descrições dos objetos da sala de visita da patroa de Félicité feitas por Flaubert, nesse conto, são exploradas por Roland Barthes como detalhes supérfluos da narrativa no seu célebre texto "O Efeito de Real", onde o autor, pela via da comparação com o romance realista, manifesta seu ceticismo contra a pretensão referencial da história, a qual ele vai chamar de ilusão referencial, uma vez que, no momento em que se indica o pormenor, o detalhe, que parece capturaro real, ele já seria significação. Os detalhes supérfluos, segundo Barthes (s/d, pp. 1316), nada acrescentariam na estrutura da narrativa, mas a sua função seria, portanto, a de dar conta do efeito de real. locado em cima de sua mesa de trabalho durante a redação de 'Un Coeur Simple', onde ele se chamava Loulou, o papagaio de Félicité, personagem principal do conto de Flaubert" (Barnes, 2000, p. 23).

Sentindo-se próximo ao escritor através dessa visão do papagaio, como que transportado mesmo ao passado, o narrador, naquele momento que poderíamos qualificar de epifânico, verifica que, ao lado da etiqueta, e com idêntico intuito de confirmação de autenticidade, está uma fotocópia de uma carta de Flaubert, escrita a uma amiga, em que dizia:

"Você sabe o que tenho diante de mim, sobre a minha mesa de trabalho depois de oito dias? Um papagaio empalhado. Ele permanece em posto fixo. Sua vista começa a me importunar. Mas eu o conservo, para me encher o cérebro da ideia de um papagaio. Porque eu escrevo no momento os amores de uma velha moça $\mathrm{e}$ de um papagaio" (Barnes, 2000).

De fato, nesse conto, Félicité, uma velha e devotada empregada de uma família burguesa de Rouen, é tomada por uma estranha paixão por um papagaio: o Loulou. Sem ter nada de seu, a não ser a sua fé religiosa, Félicité, depois de perder todos aqueles a quem se dedicara, sem nada obter em troca, se apega a Loulou, o papagaio, e quando este morre manda empalhá-lo e o guarda como uma relíquia, que se torna objeto de uma devoção quase religiosa. Assim é que, na igreja, observando o Espírito Santo, se indagava acerca da sua possível semelhança com o papagaio. No momento da sua morte, ela tem uma visão mística: a do céu entreaberto, planando acima da sua cabeça um imenso papagaio, tal como o Espírito Santo nas iconografias religiosas 9 .

Motivado pelo encontro com o papagaio, o narrador relê o conto e se põe a conjeturar sobre as possíveis intenções de Flaubert ao escrevê-lo, as possíveis afinidades e paralelos entre a vida do romancista e a da criada, suas diferenças, a presença do grotesco flauber- tiano, etc. Tudo isso despertado pela visão do papagaio guardado no museu. Será justamente um enigma surgido em torno do papagaio que serviu de modelo ao Loulou que vai propiciar um interessante exercício da dúvida ao narrador. Portanto, voltemos a ele.

Pois bem, continuando seu périplo literário e sentimental em Rouen, o narrador decide ir a Croisset, pequenina cidade à beira-mar onde a família de Flaubert possuía uma propriedade. Ali, ao visitar o pavilhão, única peça remanescente da antiga residência familiar do escritor, onde o gabinete de trabalho de Flaubert é mantido como um pequeno museu, depara-se, para sua surpresa, com outro papagaio empalhado. Tal como o outro, esse também tinha uma etiqueta que confirmava haver sido emprestado ao escritor pelo museu de Rouen, o que significava igual pretensão de autencidade, para além da igual e excelente conservação, do mesmo verde brilhante, das mesmas plumas encrespadas e do mesmo olho vivo. Diante desse fato o narrador se pergunta: "Como comparar dois papagaios, dos quais um é já idealizado pela memória e pela metáfora, e o outro é um intruso desagradável?". Colocada a questão da autencidade à zeladora do museu, a qual toma partido do seu papagaio e faz pouco caso do outro, o narrador, admitindo para si mesmo ter se enganado pensando que poderia localizar "a voz do escritor" com facilidade, pergunta-se se alguém conheceria a verdadeira resposta, e se essa interessaria a alguém além dele, que tinha atribuído significação ao primeiro papagaio. De todo modo, ele decide investigar a questão, a qual só reaparece de novo no último capítulo do livro. Ali ele nos faz saber que as várias cartas enviadas àqueles que poderiam esclarecer o enigma do papagaio, editores, universitários e estudiosos da obra de Flaubert, não lhe acrescentaram nada de conclusivo, ou ficaram sem resposta. Daí, retorna ao Hôtel-Dieu, pede autorização para fotografar o papagaio, verifica uma lista de objetos emprestados a Flaubert, enquanto a zeladora lhe assegura que o outro papagaio era um impostor. Em seguida vai a Crois- 
set, onde fotografa também o papagaio ali guardado.

No momento de fazer a comparação das fotos, recorre ao seu exemplar do conto na página em que Flaubert dá a descrição de Loulou: "corpo verde, extremidade das asas rosa, cabeça azul e pescoço dourado". A descrição correspondia exatamente ao primeiro papagaio, aquele do Hôtel-Dieu, uma vez que as cores do exemplar de Croisset eram invertidas, ou seja, a cabeça era dourada e o pescoço, azul. Isso posto, e decidido a estabelecer de vez a verdade sobre os papagaios, o narrador se dirige à casa de um grande especialista em Flaubert, o membro mais antigo da Sociedade dos Amigos de Flaubert. Apresentado o enigma dos dois papagaios, o narrador demanda ao especialista se ele saberia qual era o verdadeiro e qual era o impostor. E ouve como resposta que, quando o museu de Croisset foi criado, em 1905, e se reuniram todos os objetos possíveis relacionados a Flaubert, o conservador decidiu tentar obter o papagaio que havia sido devolvido pelo escritor ao museu de história natural. Os responsáveis pelo museu se dispuseram prontamente a atender ao pedido e conduziram o conservador à seção de pássaros da sua reserva, onde havia nada menos do que cinquenta papagaios da Amazônia. O conservador, tal como o narrador, releu a descrição de Loulou feita por Flaubert e escolheu o papagaio cuja semelhança era mais próxima à descrição.

Quarenta anos mais tarde, após a guerra, quando a coleção do Hôtel-Dieu começou a ser organizada, passou-se a mesma coisa, e outro papagaio foi escolhido e de acordo com a mesma descrição. Por isso haveria dois papagaios. A explicação do especialista, entretanto, não foi suficiente para impedir o narrador de colocar duas outras questões. Quem escolheu o primeiro papagaio; no caso, o museu de Croisset não poderia ter escolhido o verdadeiro? E por que o segundo papagaio, o escolhido para o Hôtel-Dieu, era mais parecido com a descrição de Flaubert do que o primeiro? A resposta do interlocutor vai ponderar duas coisas: a primeira

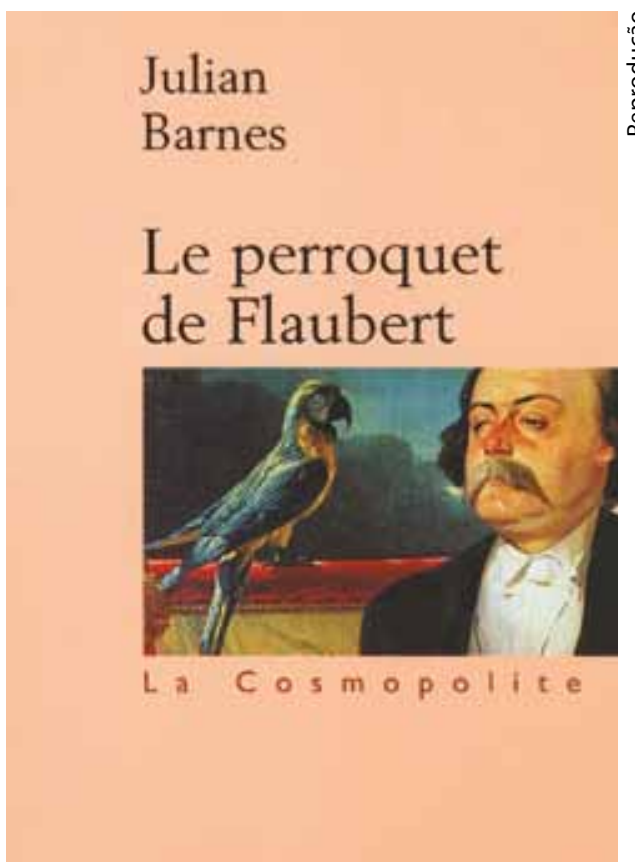

Capa da edição francesa de O Papagaio de Flaubert: realidade e ficção ironizam a memória construída sobre o escritor é que Flaubert era um artista e um escritor de imaginação. Afinal, por que ele deveria descrever o papagaio exatamente como ele era, simplesmente porque ele o tinha tomado emprestado? Por que ele não teria invertido as cores se isso lhe soava melhor? A segunda é que Flaubert teria devolvido o papagaio ao museu em 1876, depois de ter terminado de escrever sua história, e o museu do pavilhão em Croisset só foi instalado trinta anos mais tarde, em 1905. Esse espaço de tempo poderia ter sido suficiente para que o papagaio fosse comido por traças, houvesse se desagregado, perdido o enchimento, mudado de cor.

Nesse ponto o narrador se dá conta, perplexo e desiludido, de que não importava qual poderia ser o verdadeiro papagaio, ou que seria completamente possível que nenhum dos dois o fosse. Ainda assim, diante de uma resposta que, segundo ele, não era uma resposta, e de um fim que não era um fim, e sentindo que a história se desacelerava tal como os movimentos do coração de Félicité, descritos por Flaubert "como uma fonte que se esgota, como um eco que desaparece", o narrador arrisca-se, antes de partir, a voltar ao museu de Rouen e verificar, na sua reserva, o destino dos tais cinquenta papagaios da Amazônia. Dos cinquenta ele verifica que 
restavam três (com as cores apagadas debaixo do inseticida), os quais, de acordo com o desiludido narrador, "o fixavam como três velhos debochados, cobertos de caspa e indignos" (Barnes, 2000, p. 342). Antes de sair de cena, ele os olha uma última vez dizendo para si mesmo que, talvez, fosse um deles...

Diante dessa incerteza, desse sentimento de que algo foi irremediavelmente perdido, $o$ que o narrador/escritor parece nos sugerir é que o que restou efetivamente da sua busca do verdadeiro papagaio - ou do verdadeiro Flaubert, ou da verdade do escritor - foi o texto de Flaubert. Porque a sua biografia, o seu passado, que o narrador tanto insiste em recuperar na sua materialidade autêntica e numa relação direta com a sua representação, se lhe apresenta como uma rede de pesca, que o autor define como um conjunto de buracos ligados por um fio.

A percepção da fragilidade dos alicerces da memória, suas lacunas, e a inquietação do autor com as diferentes percepções da temporalidade, a angústia com a ideia de verdade, retornam, em outro dos seus romances mais recentes ( $O$ Sentido de um Fim), no qual o personagem principal, formado em história e professor de história, ao relembrar sua vida de estudante e as relações do seu grupo de amigos, recupera uma resposta dada por um colega à questão, colocada pelo seu professor de história no passado, sobre o que seria a história afinal. E ouve: "É aquela certeza fabricada no instante em que as imperfeições da memória se encontram com as falhas da documentação". A resposta abre um diálogo interessante com o professor, e a mencionamos apenas para reforçar que, aqui, as promessas de uma analogia com a problemática da identidade narrativa e ambição de verdade da história, com a problemática dos laços entre o passado e os objetos memoriais, e a questão mesma da relação entre memória e da história são promessas expressivas. E elas nos fazem lembrar que a atitude retrospectiva comum à história e à memória e o fato mesmo de que ambas se definam como modos de perseverança do passado no presente não eliminam o fato de que o passado só pode ser construído a partir da lacuna.

A referência ao ausente é, assim, constitutiva do modo de presença do passado e, nesse sentido, a perda se nos apresenta como inerente ao trabalho de memória e à construção historiográfica. Seja a perda do traço material, com alterações físicas ou destruição, a exemplo dos corpos do deserto de Atacama, seja a perda do traço psíquico, como marca afetiva do evento.

Ao longo do texto, o autor, tal como o narrador, se debate sobre a maneira como transitamos no passado - "perdidos, temerosos, desorientados, nós seguimos os signos que sobreviveram; lemos os nomes das ruas, mas não podemos saber com certeza onde nos encontramos" (Barnes, 2000, p. 101) -, inquieta-se com as possibilidades que temos em apreender o passado, que ele chama de passado estrangeiro, uma vez que "nós lemos, nós aprendemos, nós interrogamos, nós nos lembramos, nós somos respeitosos e um detalhe fortuito muda tudo", questiona-se sobre a prática e a autoridade da história, dizendo que: "nós podemos ler documentos durante dezenas de anos, mas muito frequentemente somos tentados a levantar a mão aos céus e declarar que a história é simplesmente um gênero literário: o passado é uma ficção autobiográfica que se dá ares de relatório parlamentar [...]. Seria a história uma aquarela de amador, rápida e exata?".

Nesses questionamentos, guardadas as distâncias de época e suas respectivas visões de história, o autor se apropria das problematizações, quiçá das convicções, do próprio Flaubert acerca da história - manifestadas, é importante lembrar, através dos personagens do seu livro Bouvard et Pécuchet -, o qual acreditava que a história era sempre julgamento e opinião, não era capaz de produzir um relato confiável, e que a verdade não teria morada em lugar algum. Nesse livro o ceticismo de Flaubert diante da impossibilidade de testemunho objetivo do passado se traduz no ridículo dos personagens, na crença ingênua de Bouvard e Pécuchet na história, a qual, diante do impasse, acaba desembocando no "caminho do romance" (Farge, 1997). 
Se, na literatura, o modelo narrativo, ou seja, a dimensão retórica do discurso ficcional, é um procedimento suficiente para ligar os vários buracos, dar existência a um tecido e sustentá-lo com a construção de uma verdade da literatura, nós sabemos que na história as coisas se passam de outra maneira. Isso nos remete às implicações cognitivas tanto da memória quanto da história e, por elas, podemos adentrar em outras considerações, motivadas pela leitura do livro de Paul Ricoeur (2000), em que se empreende um verdadeiro tour de force em direção a uma fenomenologia da memória, passando pela epistemologia das ciências históricas e culminando numa reflexão sobre o esquecimento.

\section{DE FRAGMENTOS DE MEMÓRIA E DA REPRESENTAÇÃO DO PASSADO}

Confrontado, como os historiadores, com os mesmos problemas dos laços entre história e memória, e preocupado, conforme declara, com o excesso de memória, ali, e o excesso de esquecimento, acolá, bem como com as influências da comemoração e dos abusos de memória e do esquecimento na contemporaneidade, preocupação que, aliás, ele qualifica de pública, de cívica ${ }^{10}$, Ricoeur se dispõe a fazer um percurso em três etapas: na primeira ele passa pela memória e pelos fenômenos mnemônicos, numa perspectiva fenomenológica, em que revisita, entre outros, os tratados clássicos de memória de autoria de Platão, Aristóteles e Santo Agostinho; na segunda, passa pela história, tomando como eixo a epistemologia das ciências históricas; e, por fim, pela hermenêutica da condição histórica dos seres humanos, pela via de uma meditação sobre o esquecimento. Ao final do percurso, uma reflexão sobre o perdão e a defesa de uma política da justa memória, de uma memória pacífica, que reconcilie o passado com o presente, vem afirmar a perspectiva ético-moral - e "cívica" - traduzida pela ideia de um "dever de memória" com que o autor reveste sua reflexão, sobre a qual pai- ram sombras de traumatismos da história europeia, a exemplo do holocausto, das guerras, das consequências da aventura colonizadora e também das violentas ditaduras latino-americanas, dos genocídios e massacres na África e na Ásia. Nisso ele não está sozinho e, embora não nos detenhamos nesse ponto, poderíamos citar uma dezena de trabalhos surgidos nos últimos anos, em que seus autores, a exemplo de Todorov (2000), Beatriz Sarlo (2007), Henry Rousso (1987), Michel Pollack (1986), entre outros, se debatem sobre o papel do historiador frente à memória do passado, a escolha entre o trabalho de memória ou o dever de memória, e os riscos e paradoxos do dever de memória; os conflitos e exigências da comemoração; o dever do testemunho; a memória do genocídio entre a retórica e a manipulação, entre outros.

A problemática comum a unir as partes do livro de Ricoeur é a da representação do passado. O seu ponto de partida é o pressuposto com o qual nos alinhamos à existência de dialética entre memória e história, o que não significa admitir o argumento simplista de uma complementaridade entre ambas. Por essa dialética evitamos alguns pares de oposição, como, por exemplo, entre uma história crítica, situada do lado da ciência, e uma memória tomada como algo fluido e fantasmagórico, ou ainda entre a memória coletiva e a história tal como pensada por Maurice Halbwachs (1990; 1994). Entendemos que essa dialética é reivindicada como uma superação dos impasses frente a uma relação de tensão, de conflito, a que a relação história-memória foi relegada, por um lado, pela emergência de uma história da memória, a qual, muito embora tenha desvelado a condição da história como produtora de memórias e aberto o terreno para a uma história das metamorfoses da memória, acabou, como bem detectado por Ricoeur, por se apropriar da memória, historicizando-a submetendo-a à história, anulando sua existência teórica e, por outro lado, pelas pressões do poder político e dos grupos sociais que impõem à história um exercício utilitário da memória, expresso nas comemorações e nos vínculos
10 Ver "Advertissement" (Ricoeur, 2000, p. I). 
11 Ver, sobretudo, cap. 2, primeira parte, "La Mémoire Exercée: Us et Abuse", pp. 67-111, e cap. 2, segunda parte, "La Condition Historique - Histoire et Temps", pp. 449535.

12 Aqui vale abrir um pequeno parêntesis para lembrar que o termo "literária" é utilizado por Ricoeur em referência a uma das fases da operação histórica, aliás, última fase, a fase representativa segundo os termos de Michel de Certeau (1982), e que Ricoeur (2000, p. 171) endossa. Nessa fase, como veremos à frente, 0 discurso histórico é colocado na forma literária, ou escriturária, e endereçado ao conhecimento dos leitores de história. Ressaltamos que o uso do termo "literária" é completamente diferente da perspectiva que lhe dá Carlo Ginzburg (2001), quando, ao distinguir história dememória, enfatiza a condição literária como um elemento definidor mais amplo: ou seja, história se distingue da memória porquanto é uma reflexão sobre a distância que nos separa do passado por meio da expressão de um "gênero literário" chamado historiografia. construídos com as lutas de reivindicações identitárias, direito de minorias submetidas. Nesse caso a memória é elevada à posição de matriz da história (Ricoeur, 2000) ${ }^{11}$.

Ricoeur, aliás, reafirma seu pressuposto com a advertência de que a desconfiança frente às deficiências e aos abusos da memória pode levar a uma sacralização da postura histórica, tanto quanto o recobrimento da história pela memória levaria a operação da compreensão/explicação histórica a um impasse epistemológico.

$\mathrm{O}$ que nos interessa reter, sem esquecer que o campo da memória é minado por conflitos, é a sua reivindicação de um estatuto teórico próprio para a memória, assentado no seu poder de ligação ao passado, seu poder de atestação em relação ao passado, enfim, assentado no fato de que a memória é guardiã da dialética do que Ricoeur (2000, pp. 364-7) chama de passagem (passeité) do passado, ou seja, a relação entre o que "não é mais" com o "tendo sido". Em Tempo e Narrativa (Ricoeur, 1983) já nomeava a memória como "o presente do passado". É essa condição da memória que asseguraria, a seu ver, o reconhecimento das imagens do passado e o testemunho oral. A função matricial da memória assim parece-nos ser bem essa apontada: a de portar o sentido da "orientação na passagem do tempo" (Ricoeur, 2000, p. 116). Outra dimensão do seu estatuto se entrelaça com a primeira por se assentar na condição da memória de fazer com que o passado se torne presente. Aqui entra em cena a dimensão de temporalidade da memória, a qual, conforme entendemos, é a responsável pelo seu caráter de atualização, a sua abertura ao presente e ao futuro - captadas pela sensibilidade de Marcel Proust (1986), transformadas em princípio heurístico por Bergson (1990), e em promessa de redenção por Walter Benjamim (1980; 1985a, 1985b, 1985c; Matos, 1989, 1993), pois capaz de unir o instante e a duração. Nesses deslocamentos, sempre reatualizados, nessas coincidências, entre passado, presente e futuro, é que o tempo da memória se deixa entrever. Isso porque esse caráter de atualização é o que assegura o vínculo da memória com a ação, na experiência viva do presente histórico, o que nos interessa de perto, como veremos à frente.

Esse movimento do passado em direção ao futuro e do futuro de volta ao passado é expressão dessa atualização, a qual, no nosso entender, também é o que permite à memória dar forma à realidade passada, fazer as vezes do fio que estabelece as ligações perdidas, tal como procuradas, seja na ficção, em torno do papagaio de Flaubert, seja na dolorosa realidade dos arqueólogos e das mulheres na sua busca no deserto de Atacama, ou seja, entre os indivíduos, os eventos e os lugares no espaço e no tempo.

As implicações historiográficas da reivindicação desse estatuto teórico na relação da história com a memória, no nosso entender, são significativas. Por tal estatuto é esconjurada a pretensão da história em reduzir a memória a apenas mais um dos seus objetos, um objeto novo, fazendo com que ela se identifique com a história, bem como com o uso flutuante do passado segundo as interrogações do presente. Por outro lado, ele permite que a memória apareça com a sua capacidade de se historicizar sob diferentes formas culturais, as quais dão forma ao texto histórico da memória. Pois, como salienta Ricoeur (2000, p. 511), "é sempre sobre formas culturais historicamente limitadas que a capacidade de fazer memória se deixa apreender".

Não obstante isso, é preciso não perder de vista a afirmação de Ricoeur (2000, pp. 1689) de que na "autonomia do conhecimento histórico em relação ao fenômeno mnemônico permanece a pressuposição maior de uma epistemologia coerente da história enquanto disciplina científica e literária"'12.

Admitido, portanto, o pressuposto de certa autonomia do conhecimento histórico frente à memória, e na compreensão do que aproxima e ao mesmo tempo distingue história e memória, uma questão-chave vai orientar o percurso analítico de Ricoeur desde o início: a de que, na sua relação com o passado, história e memória possuem pretensões de natureza diferente - a história teria 
uma pretensão de verdade e a memória de fidelidade. Essa pretensão da memória a uma fiabilidade definiria, segundo ele, o seu estatuto veritativo e a sua grandeza cognitiva, separando a memória da imaginação. É a confiança advinda da fidelidade que a teoria da memória transmitiria à teoria da história. Ela precederia a ambição de verdade da história, cujo estabelecimento, é preciso lembrar, se deu em relação à pretensão de verdade de outras ciências (Ricoeur, 2000, pp. 295-6, 364-5). E o esquecimento seria um desafio por excelência interposto tanto à ambição de fidelidade da memória quanto à de verdade da história. Os momentos difíceis da memória, ou o que Ricoeur e outros chamam de "memória ruim", ficam, - para além das patologias no campo cerebral, e das resistências, ou do recalcamento, no campo psicológico -, por conta das manipulações, nos impedimentos, nos comandos de controle da memória, de ordem ideológica e política, os quais se interporiam como abusos na reconquista da lembrança.

Pela via do esquecimento, nas reflexões de Ricoeur (2000, pp. 536-88), vamos nos aproximando um pouco mais da compreensão da memória e da história. A primeira figura do esquecimento, segundo Ricoeur, é o apagamento de traços memoriais. E ele distingue três tipos: o cerebral, corticoide, de que tratam as neurociências; o psíquico, relacionado às emoções e ao plano da efetividade deixada em nós pelos eventos, e que a memória involuntária captura na sua descontinuidade; e o material, ou documentário, que segundo ele diria respeito, sobretudo, aos historiadores. Em qualquer desses níveis, no entanto, acreditamos ser forçoso reconhecer, o esquecimento se traduz em perdas: seja para a memória involuntária, a memória voluntária, ou a história. O esquecimento, portanto, pode ser tomado como emblema da vulnerabilidade da condição histórica, e com ele é o passado na sua condição mnemônica e histórica que é ameaçado (Ricoeur, 2000, pp. 374-5).

A segunda figura do esquecimento proposta por Ricoeur é o chamado esquecimen- to de reserva, o qual tem uma significação positiva, pois é um esquecimento que preserva -, e que paradoxalmente torna possível a memória. E, podemos acrescentar, faz do esquecimento um meio imemorial, tal como Ernst Renan (1947-61) propôs a propósito da nação: a opção de esquecer para estar juntos, na célebre frase "a essência de uma nação é que todos os indivíduos tenham bastantes coisas em comum, e também que todos tenham esquecido bastantes coisas". Entre as coisas a serem esquecidas pelos cidadãos franceses, ele menciona a Noite de São Bartolomeu, os massacres da região do Midi no século XVIII, entre outros episódios.

A existência do esquecimento, no entanto, nos lembra Ricoeur, é também uma proteção contra a ideia delirante de um conhecimento exaustivo. Uma memória sem esquecimento, uma memória que não esquece nada, nos adverte Ricoeur, é um fantasma monstruoso, um espectro, que o personagem Funes, o memorioso, de Borges, encarnaria na medida exata. O mesmo Borges, no entanto, cioso dos desbordamentos da memória voluntária e das proezas inúteis da memorização, e para quem a memória e o esquecimento seriam igualmente inventivos, registra num poema sua percepção da memória como "essa forma do esquecimento que retém o formato, não o sentido" (Borges, 1990, p. 476). Daí, uma vez mais, a afirmação da realidade da conjugação - inevitável - do trabalho de memória, e da história, com o trabalho do esquecimento. $\mathrm{O}$ que significa dizer, de outro modo, que a história e a memória, igualmente, se fazem sobre perdas e lacunas.

Ambas se fazem também como um modo de seleção do passado, como uma construção intelectual. Já nos alertava Bergson (1990) que a memória não superpõe, não acumula indistintamente os acontecimentos, ela opera realizando escolhas.

A ambição de fiabilidade da memória, entretanto, se defronta com outra problemática para além do esquecimento. É o que Ricoeur (2000, p. 511) vai chamar de "enigma central do fenômeno mnemônico", "o enigma constitutivo da problemática intei- 
ra da memória", qual seja, a representação presente da coisa ausente. Essa dialética da ausência/presença no coração da representação do passado é portadora da marca do tempo, ou seja, do sentimento de distância temporal próprio da lembrança traduzido pela ideia de anterioridade, de um antes, do que se passou antes, do que foi. A memória seria assim a representação presente de uma coisa ausente, marcada pelo timbre da anterioridade, da profundidade do tempo, da distância temporal.

Ricoeur (2000, pp 26-7) nos diz:

"No momento do reconhecimento, sobre o qual desemboca o esforço da invocação, é que essa exigência de verdade se declara ela mesma. Nós sentimos e sabemos então que alguma coisa se passou, que alguma coisa teve lugar, o que nos implica como agente, como paciente, como testemunha".

E o testemunho, nos lembra Ricoeur, é a estrutura fundamental de transição entre memória e história. Isso porque "o milagre do reconhecimento não é permitido ao historiador" e não tem um equivalente na história. Essa é a diferença, segundo ele, entre o projeto de verdade da história e o objetivo de fidelidade da memória, uma vez que o nosso modo de conhecimento, sempre indireto, é sempre mediado pelo traço, seja pelo traço textual, através da transposição escriturária do passado, seja pelo traço material, documental. Essas reflexões dotam de sentido e nos transportam para as escolhas, metafóricas, e as ênfases do documentário de Guzmán, La Nostalgia de la Luz.

O traço documental é a expressão de uma memória arquivada - a qual, junto com o testemunho, marcaria a entrada da memória na esfera pública e na historiografia. Essa memória depositada em arquivo assinalaria, no caso da história, segundo Ricoeur, a entrada da escrita na operação historiográfica, uma vez que mobilizaria - e nosso autor insiste nesse ponto - vários tipos de escritura: desde a etapa dos arquivos até a escrita literária em forma de livros e arquivos oferecidos à leitu- ra. A escrita estabeleceria, assim, um corte entre o nível memorial e o nível do discurso histórico. $\mathrm{O}$ arquivo, aliás, lugar também social, e que, segundo Certeau (1982, pp. 78-93), realiza uma repartição cultural dos objetos em documentos, num gesto inaugural, é, aliás, criado para conjurar a ameaça de desaparecimento do traço material. O único problema, aqui, é que Ricoeur parece vedar à história também a apreensão das manifestações da memória involuntária no campo da experiência do vivido, o que não é, de forma alguma, interditado ao historiador, e que é diferente do impedimento ao reconhecimento tal como apontado por ele. Talvez isso se deva à consolidação de uma tradição de trabalho com a memória voluntária no campo da historiografia, ou ainda ao desconhecimento de alguns historiadores resistentes aos avanços da história cultural, de que a subjetividade também é histórica, seja a da memória ou do tempo, o qual não é vivido de forma igual e simultânea pelos sujeitos sociais. O tempo subjetivo, o tempo dos indivíduos com suas emoções, percepções e vivências, dificilmente pode ser apreendido fora da sua relação com a memória.

Outras linhas de problematização sobre a subjetividade da memória têm sido reforçadas por estudos polêmicos advindos do campo da neurologia, que, de forma pessimista, questionam o mecanismo de fidelidade da memória sob o argumento de que lembranças, "mesmo as mais vivas", e o "sentimento de convicção e de crença nelas" não necessariamente correspondem a algo que foi vivido, e que de fato se passou. A defesa dessa subjetividade radical da memória (Sacks, 2013) se escuda na tese de que não existiria "nem na mente nem no cérebro, nenhum mecanismo para garantir a verdade das nossas recordações, ou pelo menos o caráter verídico delas".

De toda forma, tem razão Ricoeur ao destacar que é o traço ou o indício de qualquer tipo, como o quer Ginzburg (1989), e o testemunho, como queria Marc Bloch (s/d), que, unidos na noção de documento, asseguram a continuidade da passagem da memória à história, e atribuem autoridade à 


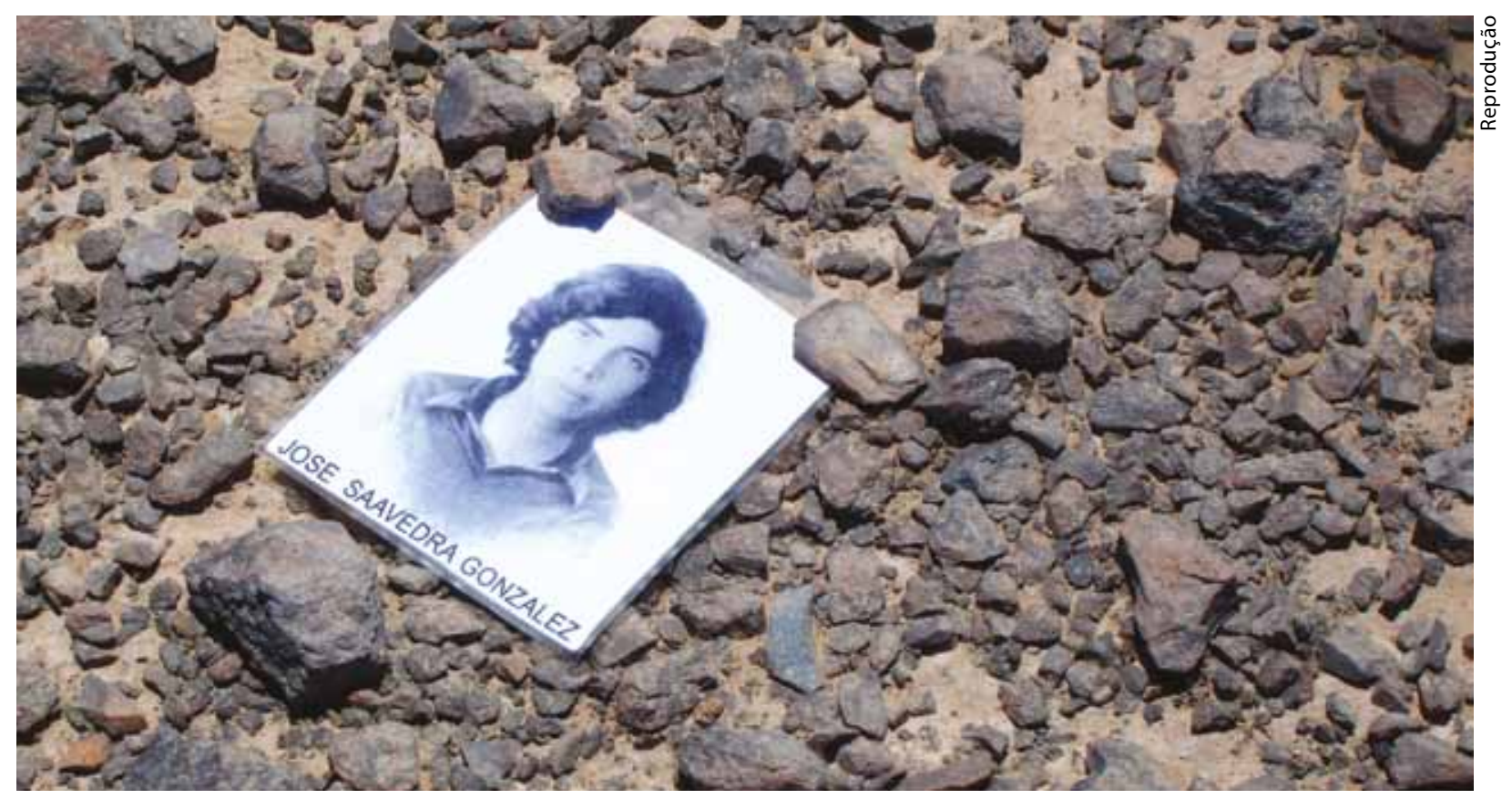

representação histórica do passado. Os traços documentais, traços referenciais, constituem, portanto, uma imbricação inevitável da história e da memória. O traço será assim uma espécie de conector, o qual, como as ruínas e os restos no deserto de Atacama, presentifica o passado, sendo essencial para a configuração do tempo, pois religa o passado ao presente. Daí Ricoeur falar de um terceiro tempo, instalado como uma ponte entre o tempo vivido e o tempo cósmico, como uma das condições formais da operação histórica. Ele configura, nos lembra François Dosse (2001), o que Koselleck (1990) qualifica como nosso espaço de experiência, ou seja, o passado tornado presente. Dessa forma, a aceitarmos as ponderações de Ricoeur, o traço, embora imerso num tempo do presente, é o suporte de uma significação que não está lá, e sim noutro tempo.

Nesse ponto a história e a memória aparecem compartilhando de uma mesma condição histórica, definida por Ricoeur (2000, p. 367) como "um regime de existência colocado sob o signo do passado como não sendo mais, mas tendo sido", o que atribui ao passado um duplo estatuto. No caso da história, uma vez lhe estando interditada a experiência do "reconhecimento" da lembrança, atributo da memória involuntária - mas que nem por isso cancela a representação icônica do passado no ato de memória -, sua intenção de representar como "verdade" as coisas passadas vai se concretizar no momento literário ou escriturário, no momento da exposição que se segue à fase documentária, e à fase explicativa/compreensiva, segundo os três momentos da operação histórica tal como definidos por Michel de Certeau.

Esses momentos são tomados na sua imbricação uns nos outros porque pressupõem que o historiador não consulta o arquivo sem procedimentos de pesquisa, um problema para a compreensão, um projeto de explicação, e tampouco explica seja o que for sem recorrer à colocação de ideias, processos, eventos em forma literária.

Embora mais abertamente colocada na fase terminal da operação historiográfica, a noção de representação, entretanto, não se reduz à fase terminal, mas é suposta existir atravessando as outras fases anteriores. Incluindo-se aí as várias etapas prévias da "explicação compreensiva e da prova documental", as quais seriam marcadas de ponta a ponta pelo signo da escrita, segundo Ricoeur e Certeau, ou pelo signo da combinação da retórica com a prova, como o quer Carlo Ginzburg (2000, especialmente pp. 13-66).

A hipótese de Ricoeur para a especificidade do uso do referente no regime his-

\section{Cena do documentário La Nostalgia de la Luz: memória e história no deserto de Atacama}


toriográfico é a de que ela não pode ser obtida apenas pela disposição das peças na ordem interna do discurso histórico, mas no seu trânsito entre o traço documental, a explicação causal e a sua colocação na forma literária. Isso não significa, no entanto, desconhecer a dimensão icônica da representação historiográfica, o que é bem diferente da ilusão referencial postulada por Barthes. Nesse sentido, o papagaio de Flaubert ou o piano e o barômetro na sala de visitas da patroa de Félicité não se reduzem a simples representações, ou significados do real, mas seriam traços materiais de um passado que insiste em durar, seriam uma referência ao real, ainda que uma referência deslocada, como nos lembra Certeau (1982, p. 53), já que "não é mais imediatamente dada pelos objetos narrados ou reconstituídos".

Noutra linha interpretativa, esses traços poderiam ser como espelhos deformantes, para ficarmos com a expressão usada por Carlo Gizburg (1989, p. 44) para designar as fontes históricas, para quem "as fontes não são nem janelas escancaradas, como acreditam os positivistas, nem muros que obstruem a visão, como querem os céticos [...] a análise da distorção específica de qualquer fonte implica já um elemento construtivo". Assim, mais do que a efetividade do texto de Flaubert, que para nossa sorte está aí para nos encantar, o papagaio, legítimo ou não, mesmo que arruinado pelo efeito corrosivo do tempo, poderia se prestar a outras construções, no campo da memória histórica, ou talvez até da memória literária. Afinal, é em condições efetivamente históricas que as "memórias" exercem a capacidade de rememoração.

De sua parte, muito embora admita que na fase explicativo-compreensiva da história a distância entre história e memória se aprofunde, pois nesse momento todos os usos dos conectores, dos traços disponíveis, são colocados à prova, Ricoeur (2000, p. 648) segue afirmando que "a competição entre a verdade presumida da representação histórica do passado e a fidelidade presumida da representação mnemônica não pode ser distinguida claramente no plano epistemológico". Essa é uma novidade teórica que, se não pode resolver os impasses da relação história e memória - uma vez que o historiador enfrenta a complexidade de articular o saber histórico sobre o trabalho de memória e no presente da história -, pelo menos é capaz de nos mostrar que a operação historiográfica não prescinde nem da experiência viva da memória, nem do trabalho sobre o traço, e nem da especulação sobre a ordem do tempo. A sua novidade teórica maior, no entanto, no nosso modesto entender, advém mesmo da sua proposição de uma dialética entre história/memória ancorada na ideia do "ser no tempo".

É, sobretudo, essa chave de leitura que nos interessa reter deste diálogo rápido - e seletivo - empreendido aqui com o livro de Paul Ricoeur, com vistas à organização do percurso analítico realizado, inspirado pelas duas outras abordagens da memória que foram sua fonte de inspiração. Não poderíamos terminar esta breve reflexão sem nos remeter para a questão da ordem do tempo e da experiência viva da memória, tal como pensadas por Reinhart Koselleck (2000, p. 310).

Esse autor, tal como já dissemos em outro texto aqui citado, sustenta a ideia da concretização da história no cruzamento da experiência e da espera, onde a experiência significa não só o poder de ter transformado o passado no presente, mas a capacidade de atualizar o passado integrando, no seu desenrolar, "os possíveis atualizados ou em falta". Isso permite pensar que o presente do passado, a memória, e o presente do futuro, a espera, são momentos correlatos do presente do presente, ou seja, do momento da ação. Do território memorial do deserto de Atacama, ao território ficcional criado em torno da memória de um escritor, ao fim, o que temos então neste texto? Algumas aporias para os historiadores indagados sobre a utilidade da história, questionados sobre as formas de ação sobre a memória; desafiados na sua consciência do que é o tempo presente, e confrontados sobre a definição social do seu papel. 
BARNES, Julian. Le Perroquet de Flaubert. Paris, Éditions Stock, 2000.

BARTHES, Roland. "O Efeito de Real", in O Rumor da Língua. Lisboa, Edições 70, s.d., pp. 131-6.

BENJAMIM, Walter. "O Narrador", in W. Benjamin et alii. Textos Escolhidos. São Paulo, Abril Cultural, 1980.

. "A Imagem de Proust", in Obras Escolhidas. V. 1. São Paulo, Brasiliense, 1985,

pp. 36-49.

"Sobre o Conceito de História", in Obras Escolhidas. V. 1. São Paulo, Brasiliense, 1985, pp. 22-232.

. "Sobre Alguns Temas em Baudelaire", in Obras Escolhidas. V. 3. São Paulo,

Brasiliense, 1985.

BERGSON, Henri. Matéria e Memória. São Paulo, Martins Fontes, 1990.

BLOCH, Marc. Introdução à História. Lisboa, Publicações Europa América, s/d.

BORGES, Jorge Luís. "El Ciego", in El Oro de los Tigres. Obras Completas. Buenos Aires,

Emecé Editores, 1990.

CERTEAU, Michel De. A "Operação Historiográfica”, in A Escrita da História. Rio de Janeiro, Forense Universitária, 1982, pp. 65-119.

DETTIENNE, Marcel. Os Mestres da Verdade na Grécia Arcaica. Rio de Janeiro, Zahar, 1988.

DOSSE, François. "La Mémoire Fragmente Paul Ricouer: entre Mémoire et l'Oubli", in

Cahiers Français. La Mémoire entre Histoire et Politique. 303(15-21), juillet-août 2001.

DUTRA, Eliana. "O que É Avançado nas Ciências Humanas", in Carlos Antônio Leite Brandão (org.). A República dos Saberes. Arte, Ciência, Universidades e Outras Fronteiras. Belo Horizonte, Ed. UFMG, 2006, pp. 25-43.

FARGE, Arlette. "Des Historiens Bouvard et Pécuchet", in Des Lieux Pour l'Histoire. Paris, Seuil, 1997, pp.134-49.

FLAUBERT, G. “Un Coeur Simple”, in Trois Contes. Paris, Bookling International, 1994, pp.13-55.

GAGNEBIN, Jeanne Marie. “O Início da História e as Lágrimas de Tucídides. Dossiê Narradores e Intérpretes", in Margem, 1 (9-28) 1992.

GINZSBURG, Carlo. Mitos, Emblemas e Sinais. Morfologia e História. São Paulo, Companhia das Letras, 1989.

"Distância e Perspectiva. Duas Metáforas", in Olhos de Madeira. Nove Reflexões sobre a Distância. São Paulo, Companhia das Letras, 2001.

. Relações de Força. História, Retórica, Prova. São Paulo, Companhia das Letras,

2002.

HALBWACHS, Maurice. A Memória Coletiva. São Paulo, Vértice, 1990.

. Les Cadres Sociaux de la Mémoire. Paris, Albin Michel, 1994.

HARTOG, François. "A Testemunha e o Historiador", in A Evidência da História. O que Veem os Historiadores. Belo Horizonte, Autêntica, 2012.

KOSELLECK, Reinhart. Le Futur Passé. Contribution à la Sémantique des Temps Historiques. Paris, Èdition de l'EHESS, 1990.

. Le Futur Passé. Contribution à la Sémantique des Temps Historiques. Paris,

Éditions EHESS, 2000. 
MATOS, Olgária. "Uma História Barroca”, in Os Arcanos do Inteiramente Outro. São Paulo, Brasiliense, 1989, pp. 31-123.

. Olluminismo Visionário: Benjamim Leitor de Descartes e Kant. São Paulo, Brasiliense, 1993.

POLLACK, Michel. "Le Témoignage", in Actes de la Recherche en Sciences Sociales, n. 62/63, juin, 1986.

PROUST, Marcel. Em Busca do Tempo Perdido. Porto Alegre/ Rio de Janeiro, Globo, 1986, vol. 1-7.

RENAN, Ernest. "Qu'est ce qu'une Nation?", in Oeuvres Completes, Paris, Calmann-Lévy, 1947-61, vol. I, pp. 887-906.

RICOEUR, Paul. Temps et Récit. Paris, Gallimard, 1983, tome I- II. . La Mémoire, L'Histoire et L'Oubli. Paris, Seuil, 2000, p. 200.

ROUSSO, Henry. La Syndrome de Vichy. Paris, Seuil, 1987.

. "La Mémoire n'est Plus ce qu'Elle Etait", in Écrire l'Histoire du Temps Présent. Paris, CNRS, 1992;

SACKS, Oliver. "Fala Memória. Quando as Lembranças nos Pregam Peças", in Folha de S. Paulo, Caderno llustríssima, 26/5/2013, pp. 4-5.

SARLO, Beatriz. Tempo Passado: Cultura da Memória e Guinada Subjetiva. São Paulo, Companhia das Letras, Belo Horizonte, Ed. UFMG, 2007.

SEBALD, W. G. Austerlitz. São Paulo, Companhia das Letras, 2008.

TODOROV, Tzvetan. Les Abus de la Mémoire. Paris, Arléa/Seuil, 1995. . Mémoire du Mal, Tentation du Bien. Paris, Éditions Robert Laffont, 2000.

VERNANT, Jean-Pierre "Aspectos Míticos da Memória e do Tempo", in Mito e Pensamento entre os Gregos. Rio de Janeiro, Paz e Terra, 1990.

YATES, Frances. El Arte de la Memória. Madri, Taurus, 1974. 